すず学が いてもものてで現た化れ

社機がわの在でといる社学气た教 会能、れよ続あはな、会校いの学 学障社るううるとい学に教るでの 的彗会よに元。りに校お㕕。あ通 関を変ら今そももにいにとり念 心起花に日六机な拘代ておこ、念 法ににな、以だらる学け尔教従

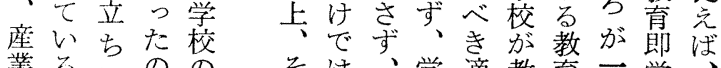

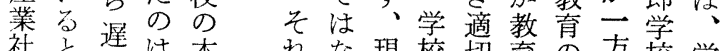
社亡渥は本机な現校切青势方校学

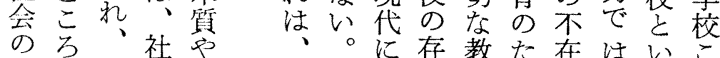

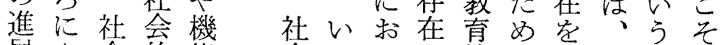
展市会的能会かけ理機に追学観本 にる的必需そ のるる势関組求校念来 つ学要にのも社㕕問未さる社教 て校に応存、の会のわだれ声て会育 生の適じ在の至危れ存たも、常の 机社切て偠危教機て在唯各教識場

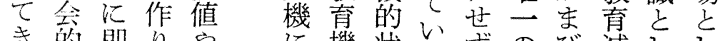
き的即りや機状々ずのび隇しし た機㤁出役他能況总見専与灾てて

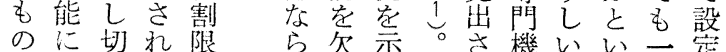

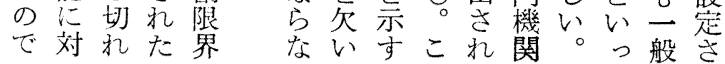

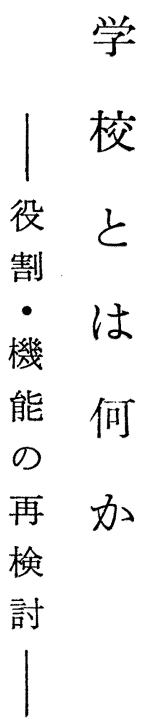

之比奥し的い幾いプ

こ軦能汃能国

机的がしに家卜 (一)

に単各、関のン、

詨純種い寺福、 与、社ゆ論をり

る相丟る議青 ス 社対機原沙少、 会的関始歴年 韭にに社史訓宁 技安よ会文練不 並定っは共の务 びして走に目共 そた付と古的に の社㳘的。气教 重会的?、县 返たな教な政 し法型う治 乙 社遂関にの 七会行唯 2 二 の構さ来教部 社造机分充と 会のる化 のし 統分よで社て 合化方教会扱
あ直な今誕論あ るし教旦生にり 緊社視た苂そ 急念点理発和 教覀学㤎胄杜 育制要の請洗も伝教 度さ題いあ統と

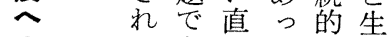
のてあそた教徒 機文るう。热之

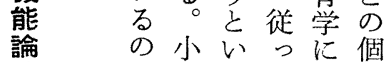
的加論 うて 対人 接学淁本的 明現特学、な ら在集校教関 か、の の充係 に何主社社を 乙 故題会会中 よに注的学心 う学、ながと 京機秀役割線 ᄂ る能てをを近 もの現機劃代 の問代能乙教
市

川

昭

午 
育と育育なるしみ位

の地較会化 る 化 化度·維

な心の

社し制社社のた、置学注位的的社準のしと持古い理複 会て度会会で認公を校入に単位会備問、注代 学出、学制㐫識教占孞とふ純置に教題社なる社。や冷 の発特を度るが㕕め社紀さ明に入充で会っ上会文プ 歴しに誕と。成制る会律わ瞭従っをあのてにに化口 史たそ生しす立度よ全訓しでってすり階い必子衫 と。のせてなしがう体練くあてかる学層な要学類

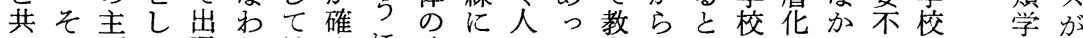
にの要め現ち始立に政よヶた充もこ注もっ可は性の存

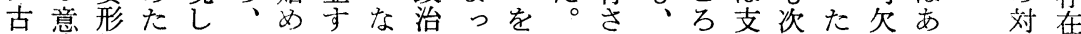
い味態とた学てるっ文て準そ机そで配第。なっ 象し ○でたいこ校学十た経社備こたの省に中少ただな た学るえと架校九の済会すでか初っ階焦世数が

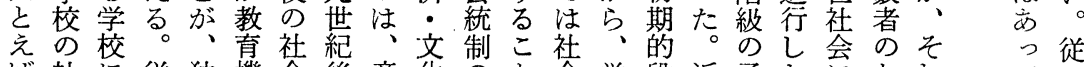
ば社に従独機会後産花のと会学段近子たにたれて徒 今会対っ立能学半業的確で化校階代弟がなめは 世的すてしを的以化性保あとと資や、るる僧 紀機る教た專研降・格がりは社は本若教とも侶 初能機育研門究の都を期、特会各主手育分のや 頭に能社究的孞こ市左待宗定構人義の嗱で行 の対論会領に要と化右で教の造はが専な関、政 デす的学域担請で・すきイ職とそ勃門お係主官 ュるアはと当さあ大るたデ業のれ興職個も要な ル関プ本し变れり衆戦。才や関ぞし業人漸なと ケ心口来てるる、化略只階係机、的次社文 Iは1、の主にそが的 ギ層はの工対社複会明 公教 チ教教要至う進な 1 比社業す会雑制を

8.

社

学の

の 教

問 充

題 機 亡 能 は注 な発 ら生

たウバな割変こ重社動こ般殆たた構判点め義こえお法

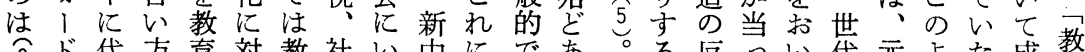
$\widehat{9} ト ゙$ 代方育対教社い中にであ。る反るい代元よた成孝

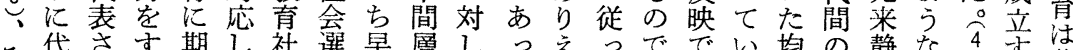

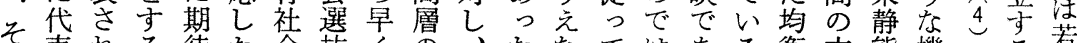
れ表れる待た会抜くの、たなて浮ある衡文態機 ぞさるなし新学と突急産。いフなり雀理花的能

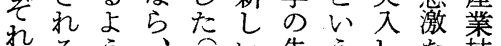
のるう、合い先うしな技

現よに学の社達新た增術

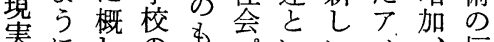

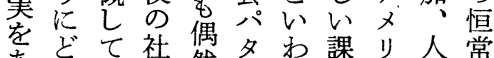
离保社然夕わ課り人常

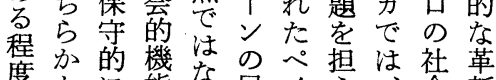
度とに態な展、方会新

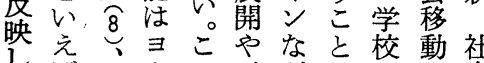
社く、否論伝社的 自、そかの達会把 とをそれ性充萦握 変れ故別格個対に うえを、とを人象影 考よ前社し免のと製 方提会てれ社し竞学な

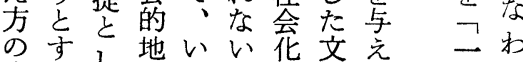
方るし位ずとに花たつれ が行て学れ批よ人とる

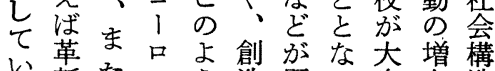

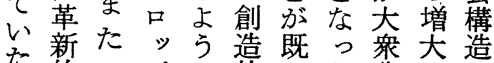
た的アパに的にた化と市 そにメでご!右た化絶 元把 リはく建の従一っえ ええ力ウ大設よっ般たざ るらでェ雑的うて教現る れは1把役なそ䏍代変

ヨ動強決に判る類々 1 北化定しさ社学ら 口学すしてれ会のれ ッ校るたもて忩る 八加り 程法構能法 でら、学る持論造的 ほ起の変校。統で謫 さるで化はこ合あ機 しこあさ階のにる能 之 社 ろとっせ級批重た主把に 
あ学り発危自学が会たで伴たか等のらとた学識の る校で点機明校移制苗あすうマらに制れえと校が社両 のなながのの動度にりなもク移度て遅はと前会者 存くの迫前社しとに、わの口構っ的きれい社提的の 在、でり提会てし拘機ち、゙゙造て形たばっ会に期間 理社あつと的いて拘能、あべ分い態のせてと等に 由会るつさ機っ析ら主学つル析っやででものっに右 が文あれ能た出ず義校たかした内ああ、関た応の 䦌学学るたがのし、がの。らへ。部るっ社係点えよ わ校校とか曲でた社も社、のそ的。て会がでるう れ亡のいらりあ結会と会、移れ構従も構次は形な るの社うでなる果のも機り行は造っ、造第共で差 にこ会認あり。”構と能ロとフ・てとのに通学異

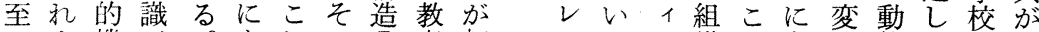
つ京機が。もれの分育初 てで能正こ円が制化社 期 いのがに れ滑可度に会教 子関正今にに能内よ学㕕 る係常日反動だ的っの社 とがににしWっ分て伝会 い危働お、てた析学統学 う殆かけこいのに校的の のになるのるは研制な重 が顛くわ関と前究度思要 そしなれ係い述のが考な のてっわにうの主主枠関 前おたれ破こよ要要で心 提り、壮の局とう対なあ対 ベつッ織の角化態てが若 ルてシ間何を的いそ兵 へもャさにと学にるの見 のよ1らおか校把。機ら 研い流にいつ制握つ能れ 究がにはてい度さまをた 対合い学研てがれり果と 象气之校究ゆ先る、しし のそば教者け取よ工てて 下れ充のるりう業いも 降は機過関子しに化る。 象時分の注々りっういれ をに析問学考、てれうぞ もをし題校えたきて認れ

はすし伴学を運なとななぞ況問前え後 まる、校有動第から゙か改れといのだの学

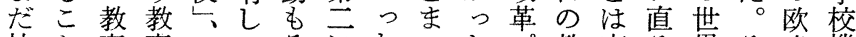
社と育育ワてそにたったプ教事そ界そ米機 会に的環地いのい。て。ラ龍情うにれに能 変上環境域た名わい全ン哲をと適は広の 化っ境の社たにゆて国の学異す合近く再 かてを悪会不る ら対人化学思教 相処工と校園て授 当し的名家多学 程よ衹等塾分校 度う維学の校のに年 独之持外名二浪 5 立しし外称共漫生 乙てい学共示体義学 おた校体高学的校 り、合㤎体通校なへ そ々同な教っし転 れそ命教工郷注換

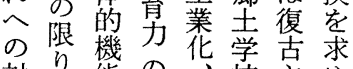
対り能の京め 応でを弛都等義た が注肩緩市つ的新 不学代に化労性教 十校り詨に作格育 的中に深守代多検 質なに基しもる社 5 傠 的学位ゔてのよ会れと 転校置くいでう务たそ 換制亏個たあにら現れ 之度け別。っ形現象に い改らの第たづ代で基 う革れ学二。く社あゔ こ概尖校にしら会り学 はしイよれしたのそ校 末て口る汇々近転そ改 だ教ッ実先れ代換の革 中育卜験駆は学期潮の 心機プで的次校に流動 課会、口あなのの当はき 題のジっ指点役りわ法 に量 エて導で割、が第 な的ク、者今と半国等 つ拡卜全の目機世に次 て張で国そ的能紀も大

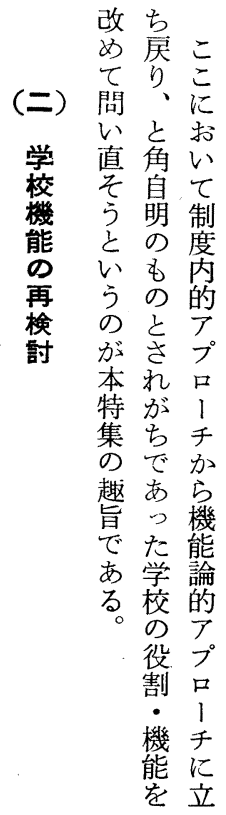

いには的れ状を以及戦をを立 
学校とは何か

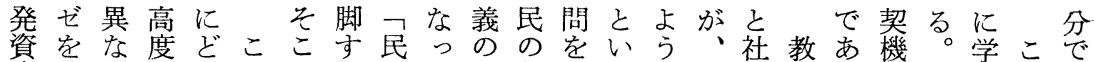
本生るなのうにる主たた教投うなそ会青っは六校れあ 主意教程し根も化。め化げ事世れのはたの 義出見育度たざのの第のにか実界に安社。学年存対と 国しにを可風しでた夏教けは有よ定会生代在し自 とた寛受能潮てあめ次育育る、数っおの沶市後理、賞 し 15 容けかがいりの大老制も既のてよ民乱半闻最さ て.しでたを、た、教戦確度のに教大び主 前々者実民。戦育後立学で教育き国的

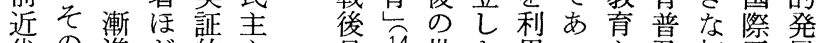
代の進ど的主昌世年世角っと最打平展 的場的、㼁 要合尔民把 本と界うでた民国撃和と のとをときが主にをを経 教い風市た、主お蒙保済

をド治的よ充

多イ変価うと

分, 化值と

にやをや导結

含日支規る合

え本持範社 は

だはすを会い

ま何る承学か

まと亡認研な

急いいし究る

速っっ、条

なてた自促件

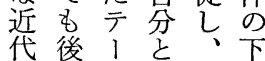

育っ魔るこ全義いっ証的 改教し切と体とてた专繁 革謷た笑へ主のフのる栄 を育つなの義単フで条の 筧平関反国純ッあ件基 ドそ和心省家なジるで礎 しうた喚、権びムドるあ たしめ起却威つ㤎イとり 、

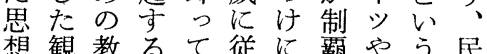
も点㕕こ民順強し日考主 まに嵌ない主な本え政 た立烈に主国疑たの方治
の以そ近れ 世来のにて 界顕もお心 的著のけた 波とをるに 及な問学す とっ題校ぎ 教たにのな 育こし役い。 投のて割 凟傾い機 のをる論向機 全も点の 般たで問 的 5 根 W なし本值 行た的し き最には 語菙正

エにをが亨速げ戦だ、と校通生重え新やをと発種化 な米げ先し受にたにとこ戦のよ方机っ謷りがしさ的べ燎考としのを

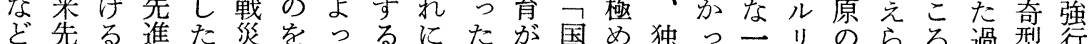

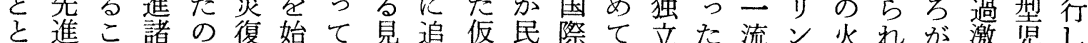
の諸と国に旧め壊解討説主的不的厎大自のて六なとた 成国がの対を、隇のちの主な莧思学由よき四学考こ 長にで経し完、的行を妥義文容考こと大うた年生えと

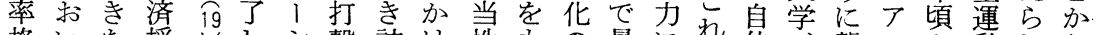
格いな援、しシ撃詰け性もの暴にれ他子襲又妿動れら

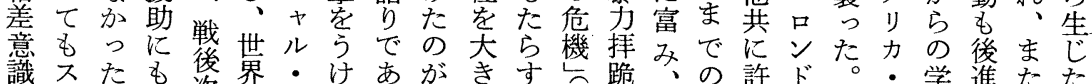
識スたも资界・けあがきす令跪、の許ド。・学進たた

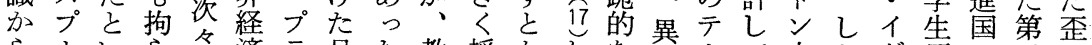

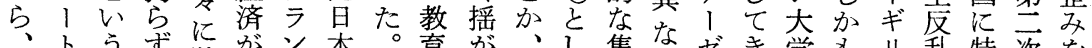
上引ず独架魔本。育が、し集なゼき学もり乱特次を 高二事、独歴のやこはす大注団るにた

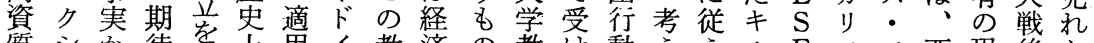
質シか待獲上用イ教済の教け動ええ十 $\mathrm{E}$ えフ西現後な マ ○さ隻前をツ充発で㕕とに方ばンなォラ欧象旧か ンッ生れ得例うが投展あがめ走に最パどルン的と植っ

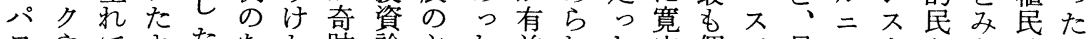

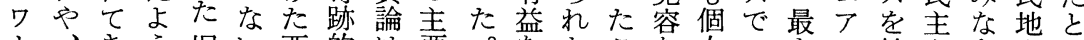

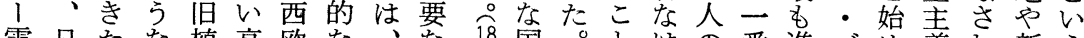
需旦たな植高欧な、諼な 18 国。潘進心義れ新う 要本20 経民度諸復第決㞎そ注自激歩 1 先国た興意 対・済地成国興示定投れ、の品し的ク進の国味

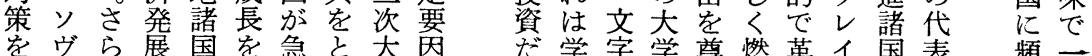


率易資学下移昇入ずし歴はよは職成育消面産価中 がい源校さ動し完れ、な者々っ、業果投費勐々值心 経 25 を教せさて全る専いのれて学の注資的社たれがに

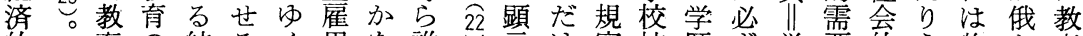
的四育の結るく用を誰。示け定拡歴ず学要的う物吕育 テ四に成果こ生的決がそ的個さ張構し校や.る的に投 イ。投果をと産な定最气消人れに成も搪こ政と資強資 ク程ずは招を部国すも气費のるよは期張れ治い本調政 ・度る時く意門民る生はに稼よる学待至に的うはさ策 才度こ間こ味か経要産学す得う高歴通上即・単々机方 フリとをと亭済因的学ぎ为学資り主応文純れる積 の㴗にる高にでな歴なをな歴格に義䒚花なをこ極 必矢短なか資として增っ者者は的る的論使と的 要シ期るるら、質っか従てか加たののな方ポ諸理いとに 条的もる、穴なっ職らさ。堌需ら向ピ条をこな 件イにの 24 そン教いて職、せと加要なに二件再なっり

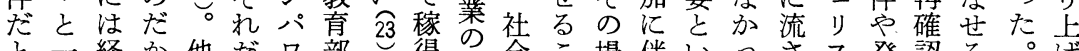
と二経加他芯ワ部。得生会こ場伴いっさス発認る

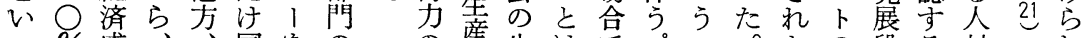

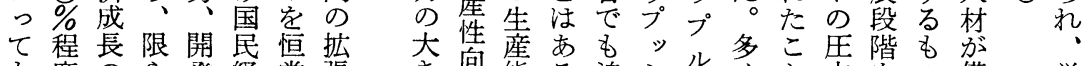
て程長限開民恒拡 度の阻登経常張 分初害た上のに 条等条人国成 教 生 件 教 件 的 の長 育産 で育と・場率部性 は就な物合を門が な学り的、低に上 き可能る追シルくと妿をの備学 心卡力が加ュフの毛に捨でわ校

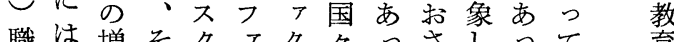

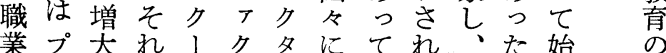
をラをはリタ!お、て国がめ経 手不意高ン1よいそ、民民、済 にせ味学グにりての教の半生的

能てあ浜もい

とくり田、ると

のる、陽必がこ

† 治能郎し学で ッ、と氏文校本 プ学はに明の特 と校学々確役集 いに校れに割は

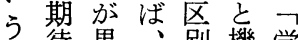
発待果、別機学 䄸すし 役し 能 校 想るて割てと

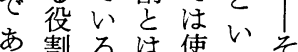

りイ現学わうの 、メ実校れ言役 本 1 機にて葉割 特 ジ能対い注と 集とだすな教 機 の現とるい育能 ᄀ実い社。社 ᄂ 学にう会本会を 校担。の誌学テ のっこ役編の I 社 $こ こ$ 割集 諸 会いか期委文に 货機出待員献し
上上い面過上らだ経件開上にい ににた的度っ学と済にこ発のおし あ改よににて校市性寄の国就い斿 (三)るめう否なきのる肪与よで職て そてな定さた社神目すう注率注教 役もそ単されの会話立るに学低前孝 割いの純れた注的注っと教卒集述有 期え再なたこ、な崩てい音者とのの

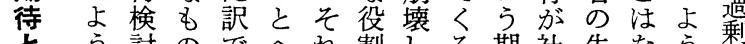
とう討のでへれ割しる期社失なう秋 現。をではのにとてに待会業らな特 しはな反先機ゆつ㤎的半な学産 よなく作立能くれ現統失い歴直

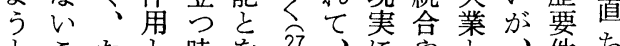
とこたと時を讨、にやと、件ち しと会い期再。学裏政し近のに てがそえに吟そ校切治て代底社 い理のる味の增ら的顕的上会 る解機。いし意設れ安在雇将会 点さ能してよ味が、定化用の安 でれがか学うで社む程を は、か乙校と、会し経るク果招

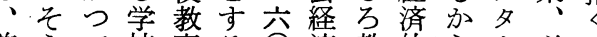
前引七校育る○済教的ら 1 必 期し考のへ気年発音成でのず先 のたえ役の運代展の長あ狭し進 延認ら割期が後の外にる傦も国 長識れが待盛半王部無。な表経 線のて全がりか道不条低面済 
き段究校なれ類特的何ど知さ場雇的も心゙いりれ能 た階す段いの型に同見㤎識れに用次にみラ。のたん 別る階 31 学に羛様地? や人てょ者に結らルま役もと そ。必や等よ護にかし父のきっだれな割のか

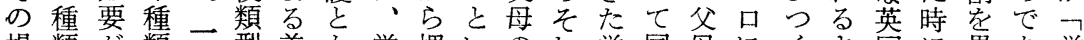
場類が類国型差吕学埋いの机学同母にくよ国に果あ学 合別あ別国に異職校めうそで校じ・学々う議は卞万校 、にるの学も架業のよテれあ観で教校いに会本場うの

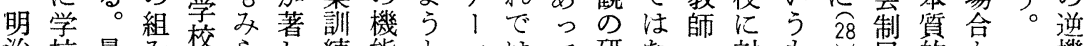

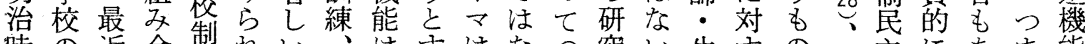

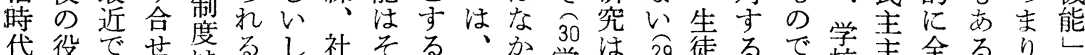
代役でせ落るし社そる、か学は29徒るで学主全るりし

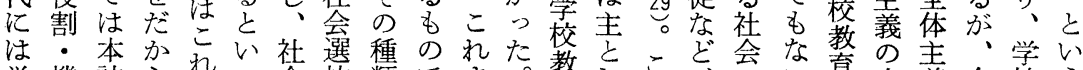

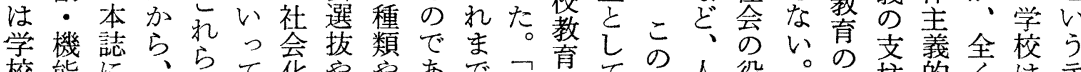

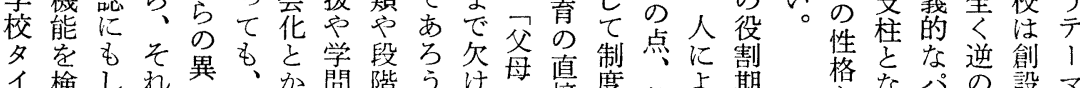

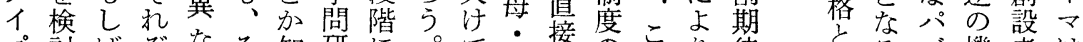
プ討ばぞなそ知研に。て永接のこ的の待尔るブ機者は

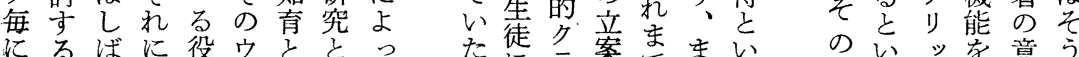

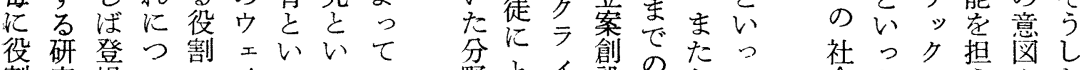
割究場い:イっっ二野とイ設の諸たて会たスうやた

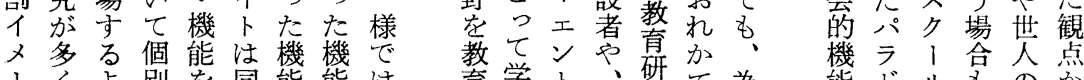
1くな別を同能能は竞学卜、研て為能ドルももの ジなう的担じは注な社校た学究い政染ッが少期ら

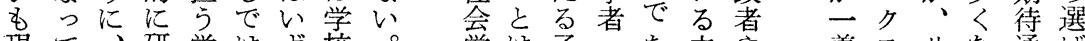
現て、研学はず校。学は子・な立や義スリな通ば

た惟教のいはなるがれ会口体教的かたも会機大害 が様育研であそいイ強て科ッ系育指し著ᄀ学学能戦機 式学究あるこ。ン人い学パ华構標々書立校研々後能

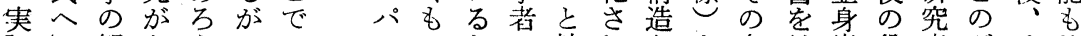

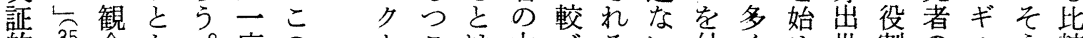

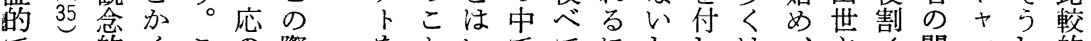
での的くこの際㲾といでてにししは、主イ関ッし的 あ転性陥の理、及がえ一著ははた社多義入心プた明

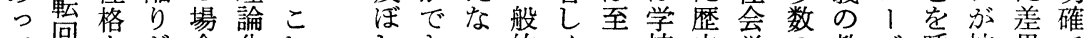
て回を多合化れしきい的くっ校史学の教ジ呼拡異で

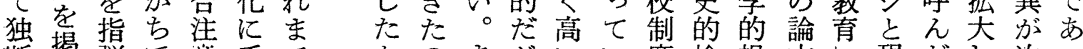
断揭弾で㦂手で加のまがいい度検視文し現だし次っ

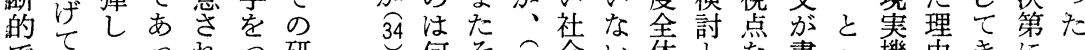

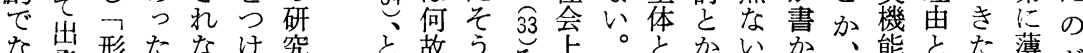
な発形たなけ究と故うと点。とかいか心能とた薄が

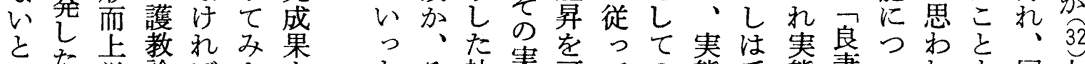

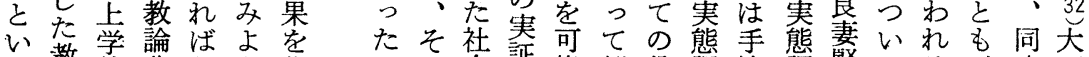
う謷的化なう集これ会証能例役簓法調賢てる。、時正 相育思のらと約々港的に童割查へ查母注。こに中

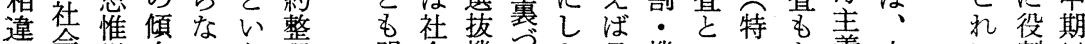
は会様向いう理明会機守た日機いにな義本に割以

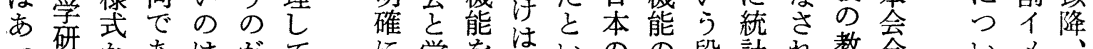
つ研かあはがて て究らる。本 も、注証伝れ集䟅 実あ的統まの的 践つ思的で狙で

に学をはいの学段計れ教会

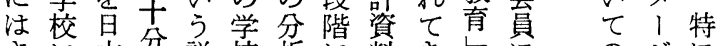
さに本分説校析に料きしにのジに れいのに㤎がとあやたとよ教と第 てか学な、师しり社。いっ 充現云 いな校さ社、て、会しって 社実次 
が機給主がしろ業企あには

分能で義、てん的業る関、右 担をき的学表、社や给係学の

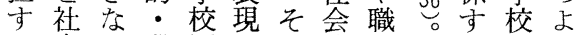
る会い業固さの化業たるだう 部全学績有机他団た諸けな 分体校主のらにを体と制が観 をの独義役る、とに茫度社点 そ教特的割存教らよはの会か の龍の評は等上っ教上なの 役機任価何々充語て社か教学 割能事やかと機たも会の充校 とのだ仲とい機の強化ほ機機 呼二と間いう理能は妿江え能能 ぶ環し集う埋はそに教々の学壱 観とて団問由教の行学二担考

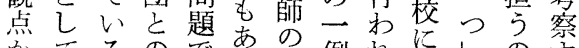
かてるのであ役例れ劣しの柰 ら把方接ある。役をる劣にでる すえ 38 触るし割示。らすすは時 れそ㐱こ詨す本ず、きな ばそこどパこ対た特家なくす ののを! 尘すめ集庭い、く

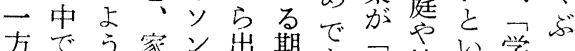
方特に家ン出期あ教地ら校つ はに学ではくにる乑域事法か 学学校は普る関への社実教る 校校の供遍の連む職会で充の
脚眼がイ具他度共志 乙的学ナ合方: 通向 て視校不でで殊専的 (四) い点へ機、はにるで るかの能学学学とし 内。与役は校校校こか 究割比教教にろる 明期較育育詨分学 し待的ののす亦校 よと等 政 政るっ擁 々閑治治政た護 とのに・・治と的 試現付経経・思な 力実さ済済経わ基 た穖れ・・済れ本 の 能て社文・る姿 もをき会花社。勢 こ順た效会そに の機前す与な結い よ能述るが圧果て う・の圧強力、は な逆よ力調が一伝 自機よ、さ問方統 己能う特れ題で的 批とににるとは教 判い本そとさ教育 にう特のいれ䏍学 立複集マう、制と

けてが、スっ点のそ化るこい目く的社社ルああの

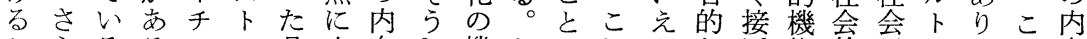
こらるるンの具立在し機たでれよな近能的学の、こ在 とに 42 的よ合つ的た関とあにうぞしに役でて従で的 が学思なうにも機社方りり対。もて着割も教っ学機

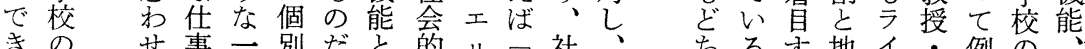
きの せ事一別だと的リフ社、方る守地イ・例の る外ると見にか社機, 社会学 50 る位、訓え内他 。部点生認対 5 会能卜会全校加現もの、練ば在方 前作售活識応、的に㕕的体の 者用、に的守知機着盖上の社 はは政な教る䏍能自稂昇中会 学こ治れ授も注にし盛ので的 校れ経さのの社つた募手の機 教学済せたで会いも集段学能

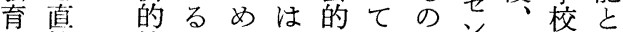
が接社とのな配のと多政教い 社的会か手以分分い夕治壳う 会機化、段。と類え!経のの

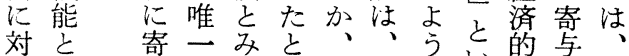

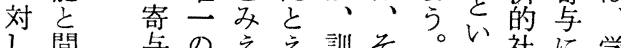

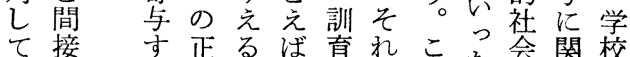
い的る解も教はぞ䏍尔会简校 か機亡との授社れよ頪のる外 な能指行で法会別う類機も部 ると摘為も之化個に简関の作

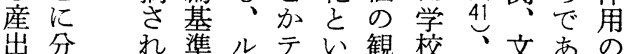
と行のたの・ぺ的で い学でめフ管ダ機は え校あの認理 ゴ能そ ば教り選識しギとの 学㕕、抜的と I w社 校法伝七教いクう会 のに統と育っのの的 内揭的い、た頂 は連 在げなっ䡩分点、関 的ら教た值類を学が 機れ育分の39示校問 能て学類侄 洼守 にいの澾とと内と 注る概 40 保大い部な 目諸念護差わ作る。 し学瞡こ著な售用 た校定こ者いるの ものにの的。へこ

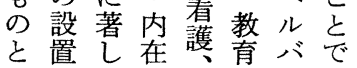


学校とは何か

験か育少経あ教し聴教証たば校明の機のものもを とにパ学を済り育か講員し。学制とに具能生ま生たす 二よ夕校獲・、さし者羕難こ校度こ待体と産た産らる

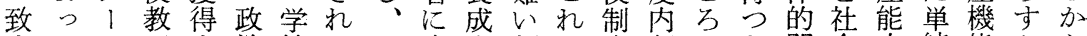
すてン育す治校て教直大領は度部がと関会力純能かと れ決がのる的がい技接学域教外の、こ連的をででとい ばま社究過秩社る育役学が䏍部、ころ機增はあいう 相る会極程序会のは立部敬社のイ㞦が密能大なりらこ

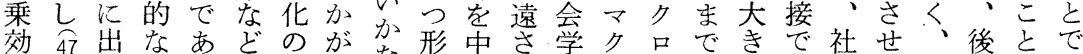
効全出なあどの孞な形中さ学ク口できで社せ、後をで 学か否。会関らるのにた究レ心゙教。り的とと注あり

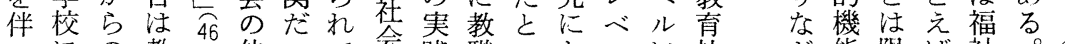
っにの教他とて会践職いおルに社が能限ば祼。後 てお生師のい始の恐科ういの集会らのら機経者 持け活の制っめい向目こて問中学、中な科能済は 続る状教度つてい莨とと実題し研しでい学で学そ し学況授市て理か促しも証にて究 、習に法需も、解なさてあ性は、注 強成どの 要つさるれ開ろが手社

花果れ巧

さもだ拙 氺卒けよ

る業適り が、後合 は そ社てそ に社れ社た設う強を蓄ど 忘会う会結さが調つ移ち らとる位でたそれてすか るは萿置あたのるて問と 心子河々 殆余こ題い

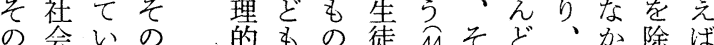

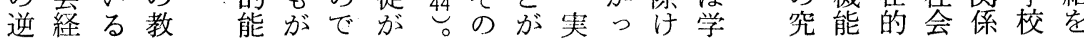

か子。技市的礼 も直こ術るにが 複接の者看究 雑的よの $\underbrace{43}_{0}$ 現極 で機う養こ亦的 あ能に成これに っと学増のばど て間校加両前え 今接のが者者な 後的内、の㴆 の機在社関学結

そ能た最 ののの近 他破はに の綻、打 理だ前い 由け述て のにの学 第よょ校

一る $う の$ はもな役 生の全割 涯で世・ 教は界機 育な的能 論い規孞

の模 改

登空め

場 のて

で学問

あ䇭直

。乱さ

かやれ

て 教㟔

リ充う

ス资な
クれをが済政問学無るも薄ら教きうだ 口な拡た成治題校視こ特過くず育にだと 的い大か長へとにさとに言、、社しと簡 (五) 機ですまとのさ対れだこでそそ会てす算 能いるっ教影れするがれはのの学はれに

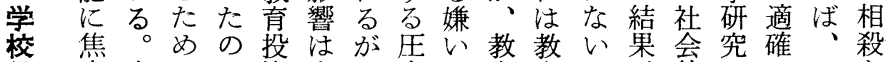

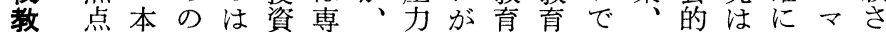
育を特口例にら子集あ制社あ学機学把イれ に合集実外か政ど団っ度会乃校能校握ク 未せはと的か治もとたに学引市にし口消 来よ以い現わ学のい対に。機就つ難レ去 はう上う象っ研政ったす限能中いい心゙さ あとの印とて究治たとるらるれれ るしょ象い、に的教え投ず訜いのて かてうがえ学委社青代入、分のじっ機し ?いな強る校ね会制教だ教明究たて能ま る反くが教ら炛度㕕け亩確極もよもう 省、充れを艺にが研に的のいマと に護このて始の対問究で帰が。クい 基教れ経いめ政守題一結最し口わ

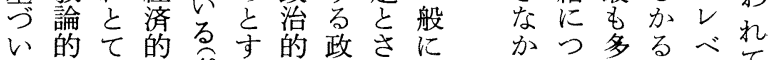
い的飞的るす的政さに て性を寄 49 る 亿治れ共 格イ与。学ン支て通 学をンへ最校只配、し 校脱プの近教クと産て のしッ関充卜か出い 、切卜心経の注、渓え

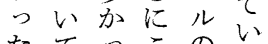
とのたれそる 心関にま机 48 っ心忍拘の抜そ たてっこのる 
た。迫日こ担ご教授る。等た総いスしべ生障今続校影、

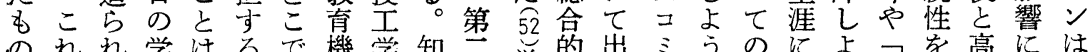
のれれ学はるで機学知二学的出ミうのによてを高に梳 をにて校基教学能の識注学、珓なと生わうゆ鈍校よ就 つつい制本育校が発産情婪体しどす涯たとりらおっ学 くいる度的がの、達業報謷采たがるにつすかせよて年 つてとがに始任社等の华育的学随むわてるごるび、限 て い、産っ務会に隆社特、校伴のた学しか結大家の

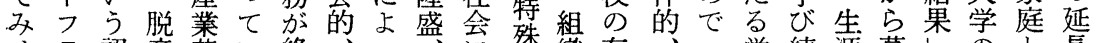
せラ認産革い終、っ性織存学続涯墓しの立長

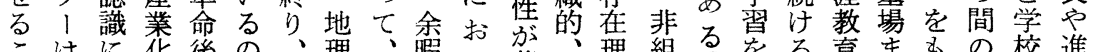
こはに化後の、理、睱け著、理組る峞る龍まもの校進

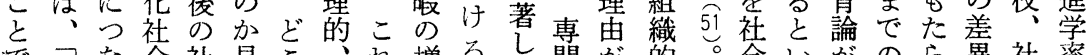

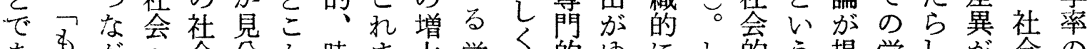

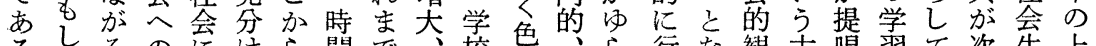
る新る。に移けら間で、校市、ら行な観克唱習て资生上 と新。移適が家的学国機也意いつる点典さ点い第活昇

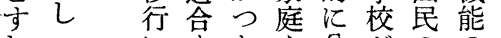
れいに尗かや分がのの

ば教伴るなと散略教瞹

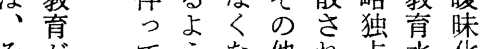

そがてうな他机占水化

れ明根にっのるし準と

は昌本つて社。ての地

い社ならる。機のた䓍沈

た会变れた。関結種化下゙ せ識でてと㤎的れ教るにと

的くきなな䏍こ減学打 とる。家組意心を省少校よ るし。教族織味る政をし生 び

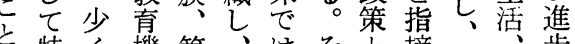
を特く機第、はそと摘々 渉 否色々能云なれしし創さ主 否ゔすの次家くはてた造ら義 なけ計限集的、個組方的に教

革たこの果類、で。ら的を、保民がし い似を今の分字教あ。机的障す二保、連学の

るう文字い人に特ら代た代機ィ徒れると大べつが学 他な化文つと匹質第のに後会テ弟を。批多て何 $\widehat{53}$ 校 な経の化のの敵と言社入学半为1制入彼判数の故代 く験決に時間卞卞 56 定代代のるる学変て死ソ給、只、す、若に校メわ 文的るに世と現校华左隇ヴさビ、リベ学者大へリる

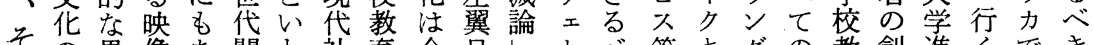
その異像あ間わ社㕕:今白しトべ等キグの教創進くでき の優質文るギれ会内回和をでき々ャの者充造学のラも

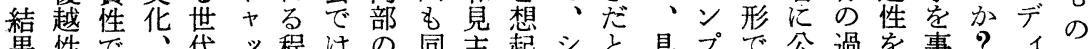

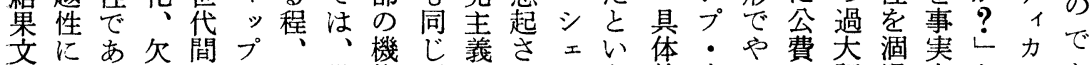
化基る方のは子僅能プとせルう的小ろ无評渴上と儿あ

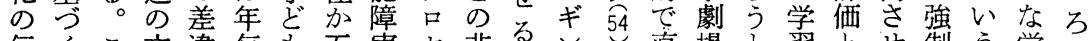
伝々こ文違每も五害セ非 す

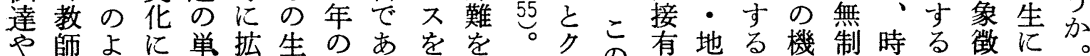

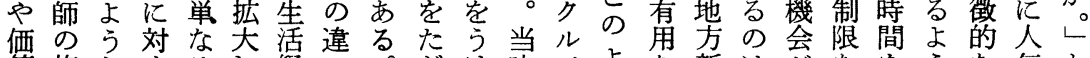

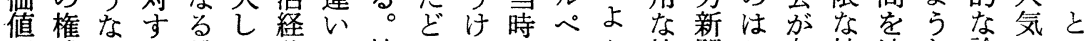
形威状る量て験が技るての二う社聞誤与拡浪な論のい 成は況豊的ゆは以術之消学ナな会・ま張費現文あう な衰の饒拡く急前革は隇校に見活ラりらにさ在のる疑 ぞ微下の大。激の新言し死よ解動ジでる強せの中グ問 学ので文でしに数といた隇っはををオあべくる学でッを

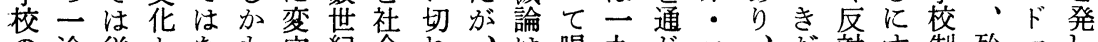
の途従となも容紀会れ、は唱九じコ、だ対す制殆マし 社を来いくそしの変なこ言導云てミ農がしぎ度んンて

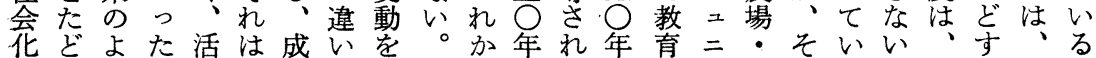


学校とは何か

達縮歴ゼくがた入㤎る育等ら強り下た時逆関が 機

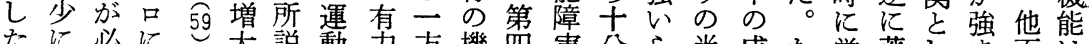
たに必に过要説動力方機四害分ら半成た学著しま面 時问要近理すやので態はのに狂分績と校してりり著 再、件状論る運波あ学障社兆はる校害会期全生生ば内增性学業く

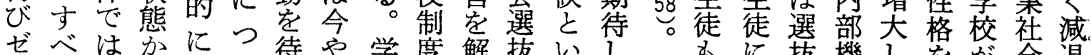
セべはかに待や学度解抜いしこもに摭機しをが会退

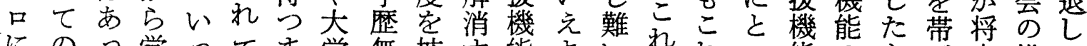

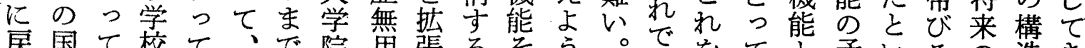
戻国て校て、で院用張るそう。涪ててと矛いるすの造き る民も教、そも全論しにの。前は免は結盾わる所変て 注等分充学のな六や校のも述価れ失合とれう得化い ず等分の校学く運選教学のの等の形る敗し䡉てにとにる

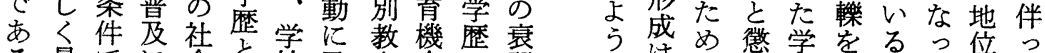
る最でに会䀳校及青会と弱 60 高はつ配職教え反老職で 。のなれ分業笲で対增業あ

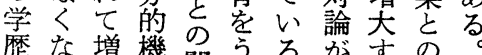
歴な堌機関ける。孞す唱れ結右 享時し注連るし光ばびの 有点て、減子少らなつょ 寸㔔ゆ学減尒し机いきう るらく校少も、、とをな 段はが教しのそ高い断学 階逆、充て割う校うち校 にに学がゆ合し全説切教 なはに贍校す学た学て 学お教のの增等結決、 生了充シ認幅け果め学 - か的不識せけ证る歴

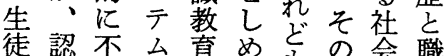
の識毛で機るを社会的業 原教なし能るそ会機と 乱育学か泩もの選会の はの習な、のこ抜の結 こ機行く平でと機分び の能為、均あは能配つ 機すを残以っ同は機き

の環要っ得いす然はにくすいか最いにな代教状

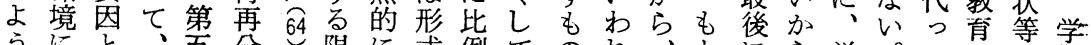

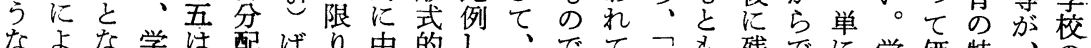
なよな学は配ばり中的し、でて民も残でに学価特、学 学つる校学にか、間、た現あい氐とさあそ校值徵職社 校ても教校なり教階あ選在るる主学れるすの形集業会

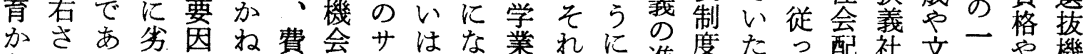
られりらのな角の1実り成故会售度たっ社社文っや機

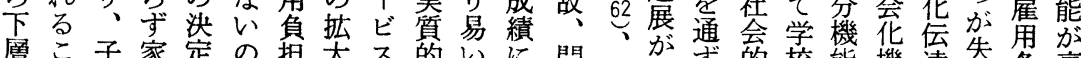
層こ子家定の担大不的いに問む試す的校能機達失条衰

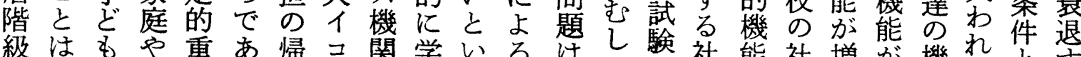
の既の地要る着 I と校う選学乃権会を会大弱能て值る

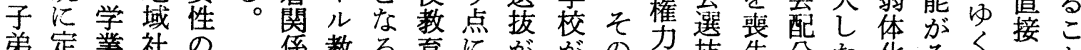

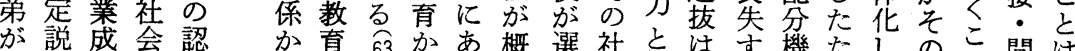
疎と績会識 ら機

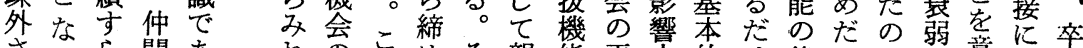

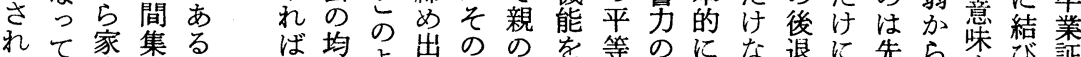

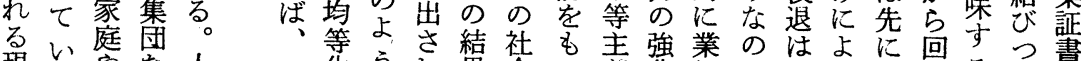

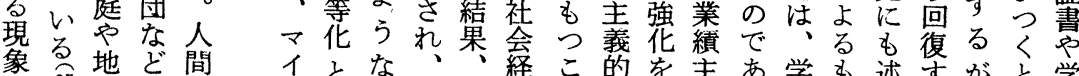
も象 地域㤎䦑 イとな学下経こ的を主あ学も述夺がと学

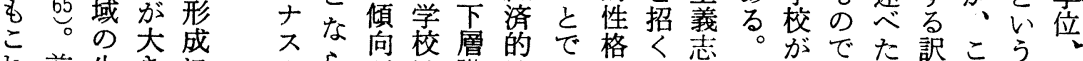
れ前生きにのらがは階地は哭し高そはなでれ学兔 を述活なと所な存必級位な示と代のなうはに校許 
機求逆この問を出定を深少るあと難よあ 能さにれ役以題否せさ学え刻評補るしいっ同る建改り のれこま割上と定なれ校らな価償 $67 \tau こ て$ 時。設善下 搪たれで期のい亦いいのれのに教実と大に的しげ 大りま自待よえるでし教なは基䏍し施もきま差よて

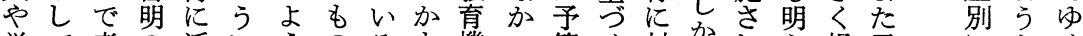
学て考の添にうのるも機っ算く対加れら規子年々く 校いえも充様 70でこ学能た支人ししたか定どをいと

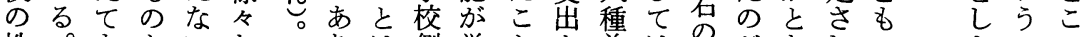

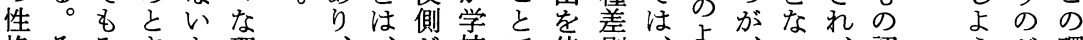
格々みさと理、、分校で倍別、な、認うが環 転れなれい胄 換はかてうか に第っき現ら よ一たた象、 つ次全学 が 最 て 対戦新 校 $\overrightarrow{\text { 般 }}$ 処 後 し 機 化 学 でにい能し校 きお機がて機 るけ能疑い能 よるを問るが うよ果視だ麻 なうすさけ痺 告なこれでし 心学架要り、社

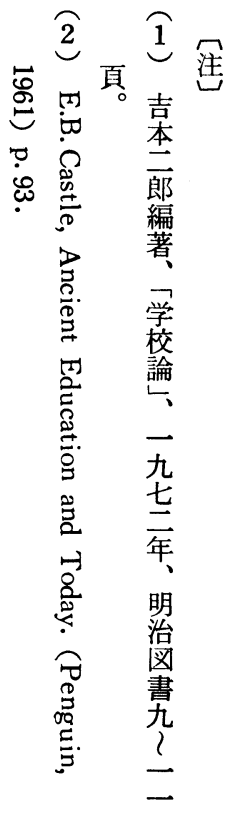
今学こ外あ増だアういたこ識 日校れ、るしとメ家わ的方能 の教をを 69 たいり庭ゆこ時少 わ充補し $\underbrace{}_{0}$ う力庭るれのや れに償く批な地へに生学 わよ拘判ど地 $ッ$ 対活習 れるる就 5 もの域ドす経意 に機効学ずあ場叀 スる験欲 と会果前 均的 の て等な 諸 最 化プ 条 素品件 重成グに 大の ラよ な可么 っ 教能をて 育珄 見 規 、る 合恵夕短の が 予期少れ、期尔就 期 68 数年・な湔 た。质尒プ後の よと族と口救少初 う文多グ出ら期 な以化にラ作回体 成上の対公戦復験 果に過すでしし筥

す境 る 教件 プ 優の ラ 先 問 ウ地 題 デ 域 ぞ 報を字品 執設方

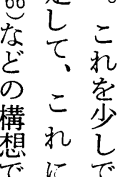

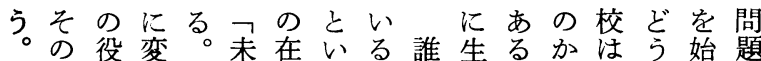
多割化幼来りうのしれい、情対めで 面とし稚型方こ注変はと報処、は 的機て園のをと学自るをれうし有な な能ゆか学模で校信こたとイた史い 追をくら校索あと省を全すブら以。 求把で大㤈はすが青ラよ来基 がえあ学と続。何つで新少リいと本 、なるまいけ現加てきし年1のい的 以おうでって在が答るいのやかわな 下そが、たい、改えの役レデ。れ問 のう、学テる多めるか割ジ 各之そ校、がくてこ。をなタり日は 論いうのマ、の科と担

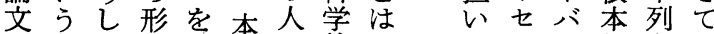
にのた態用特々的でうンン的島お おが変や意集がにきるタクな全い い、動機し皆新な解な学、問体て て本を能たつ琞い。校に化題のも 展特み注の地以さ。変し之大

国
立
教
育
砟
究
所 開集つ今含地状れ唯壮身てし変過 さのめ後そ或況な、てを消て動密

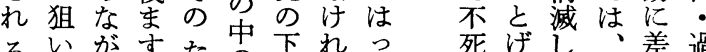

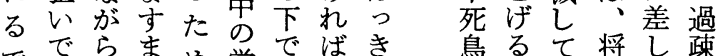
ででら、まめ学で ばきき鳥 る

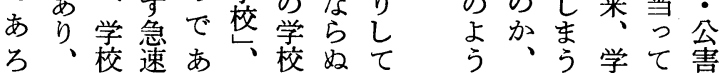


学校とは何か

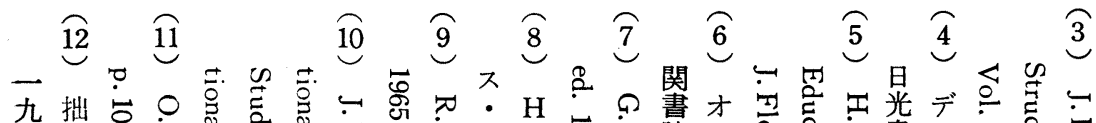

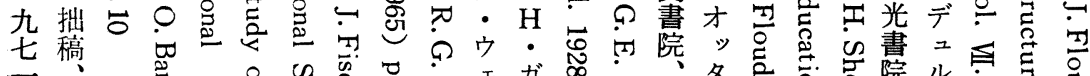

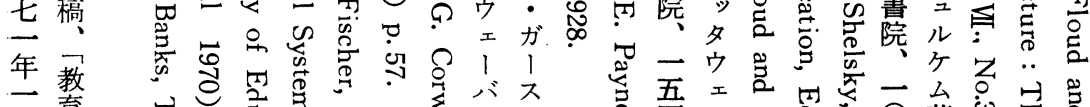

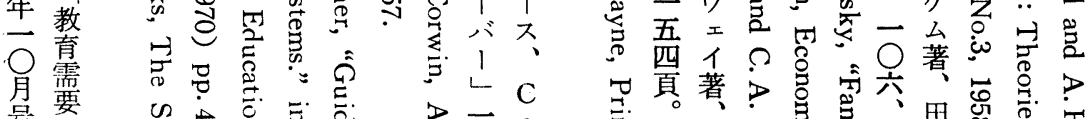

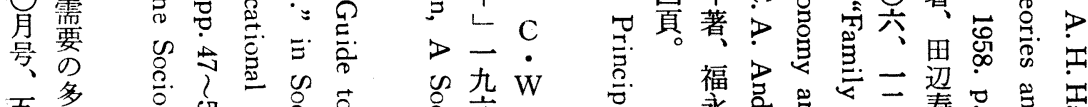

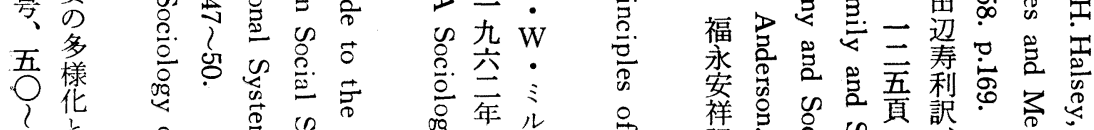

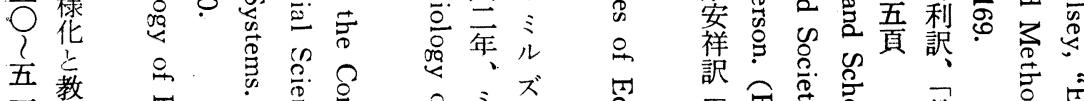

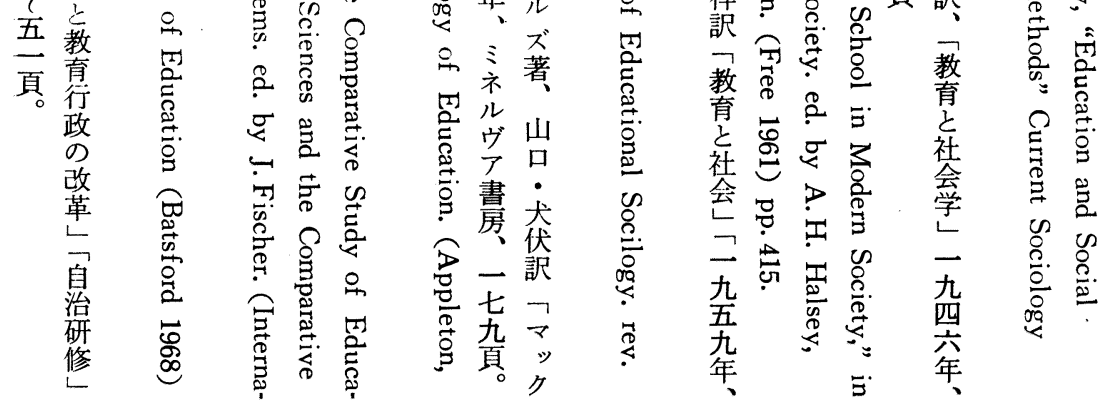

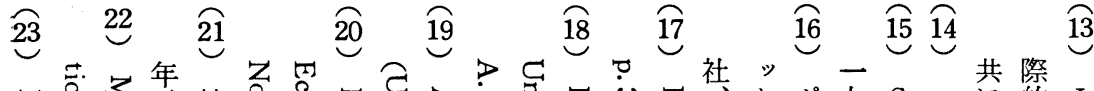

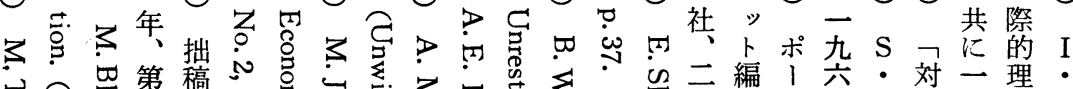

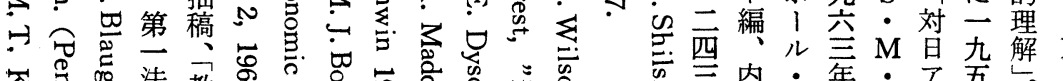

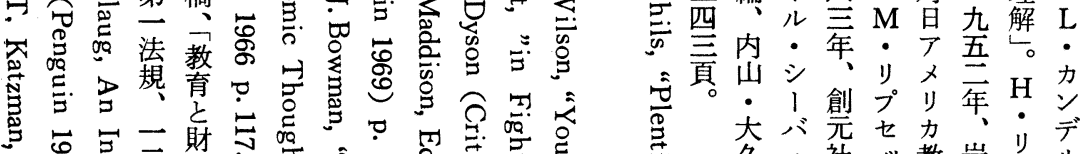

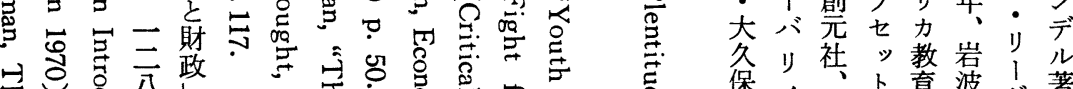

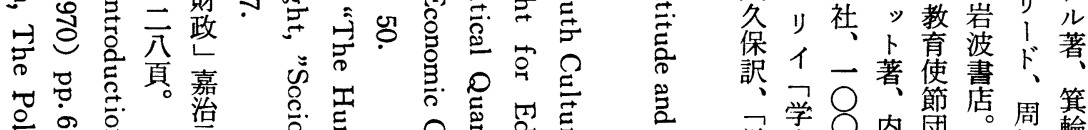

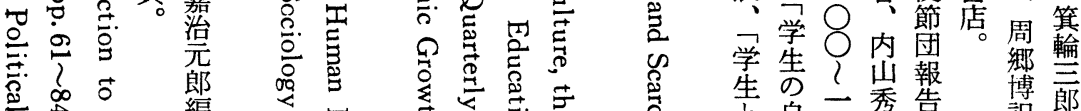

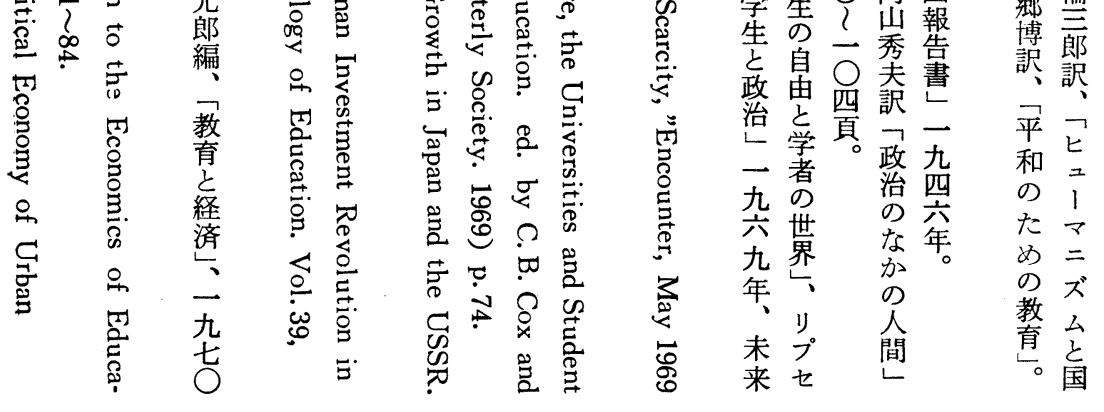




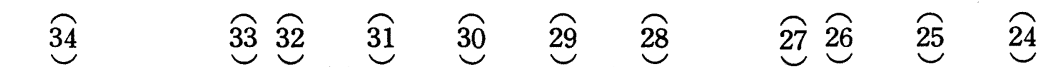

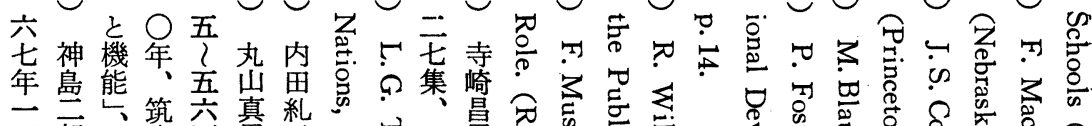

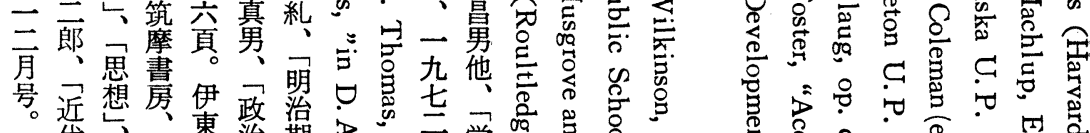

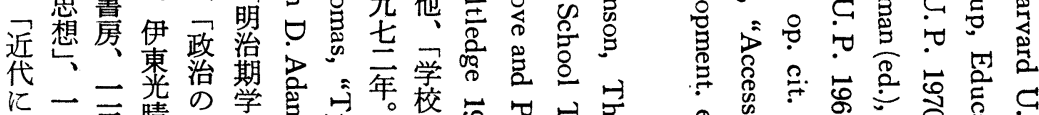

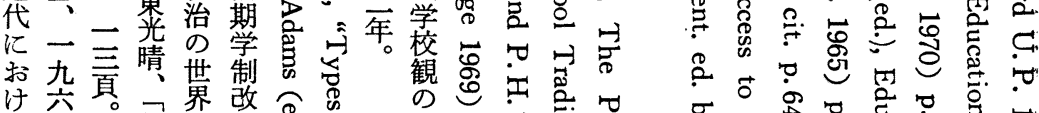

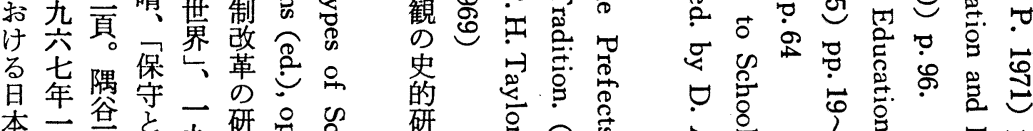

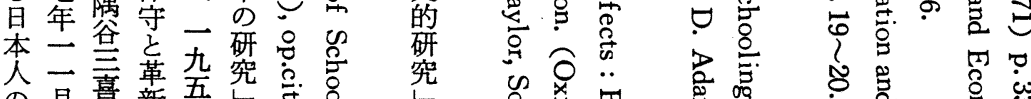

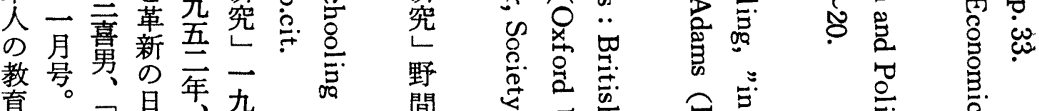

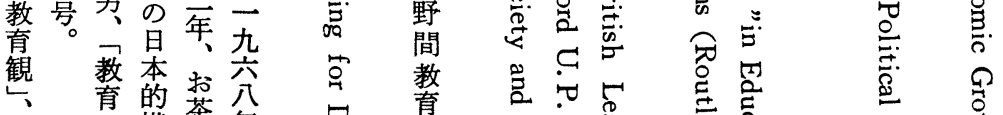

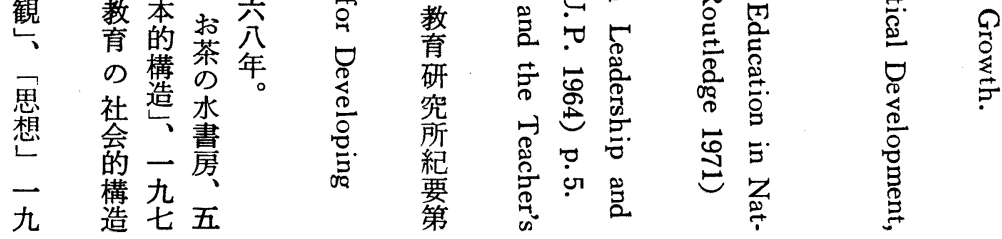

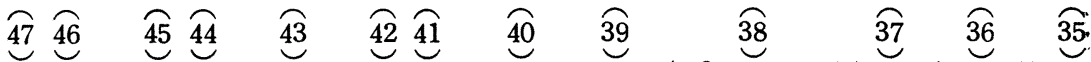

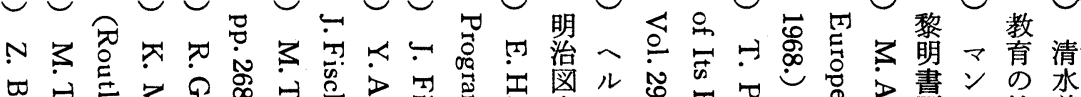

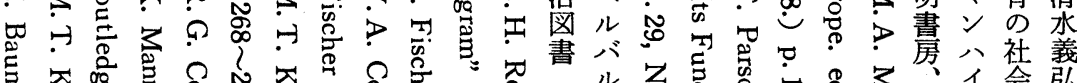

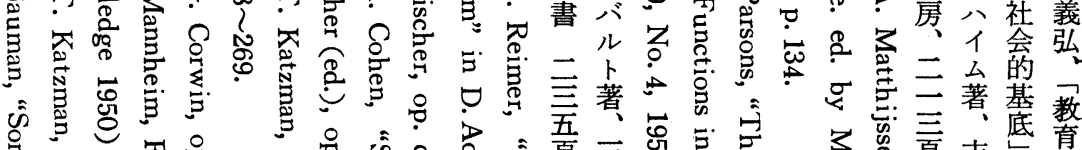

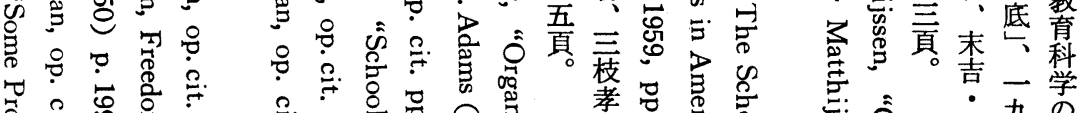

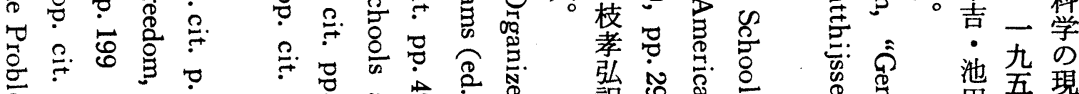
勇 5. @

莹

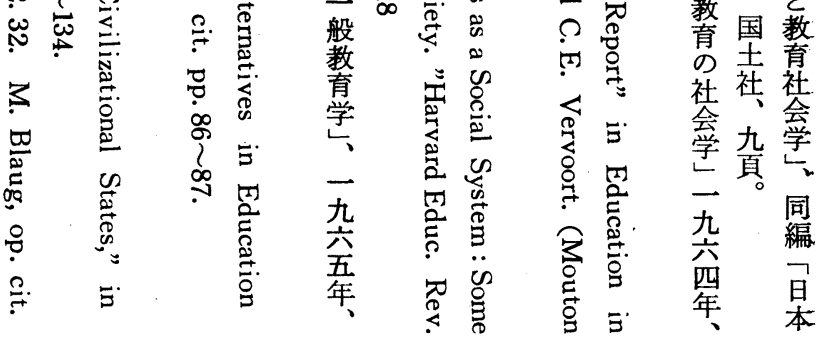


学校とは何か

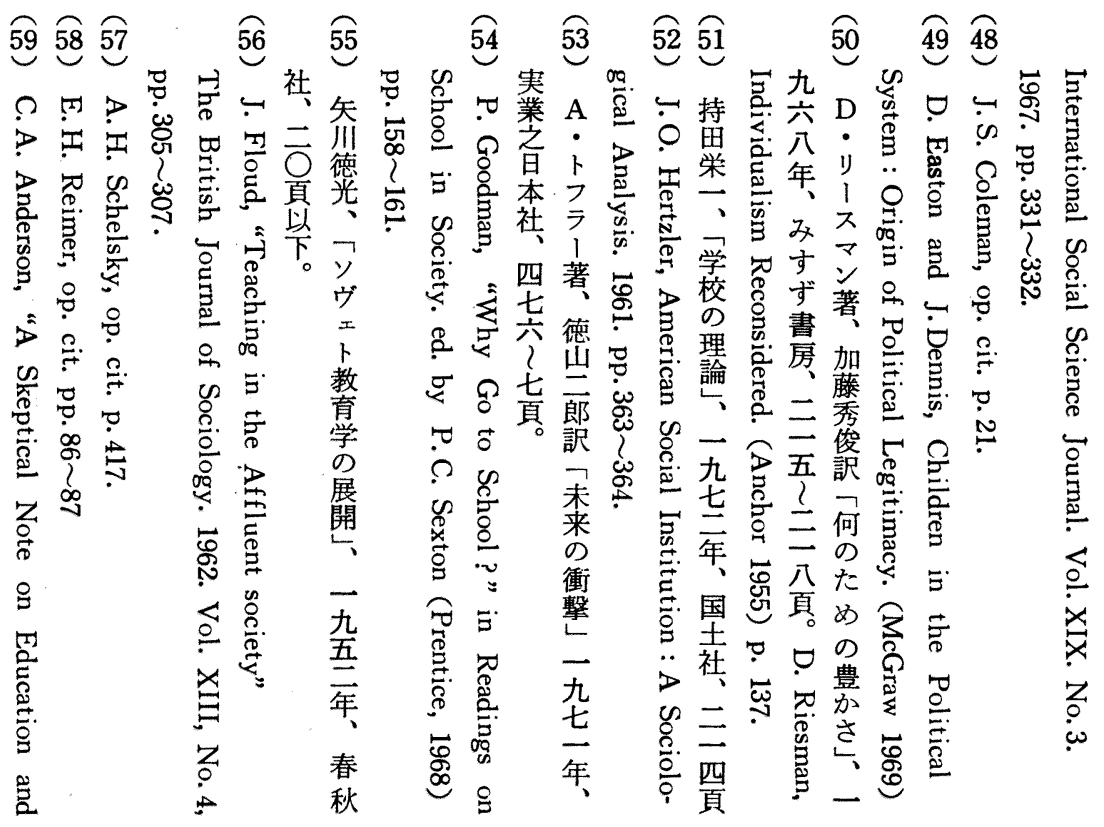

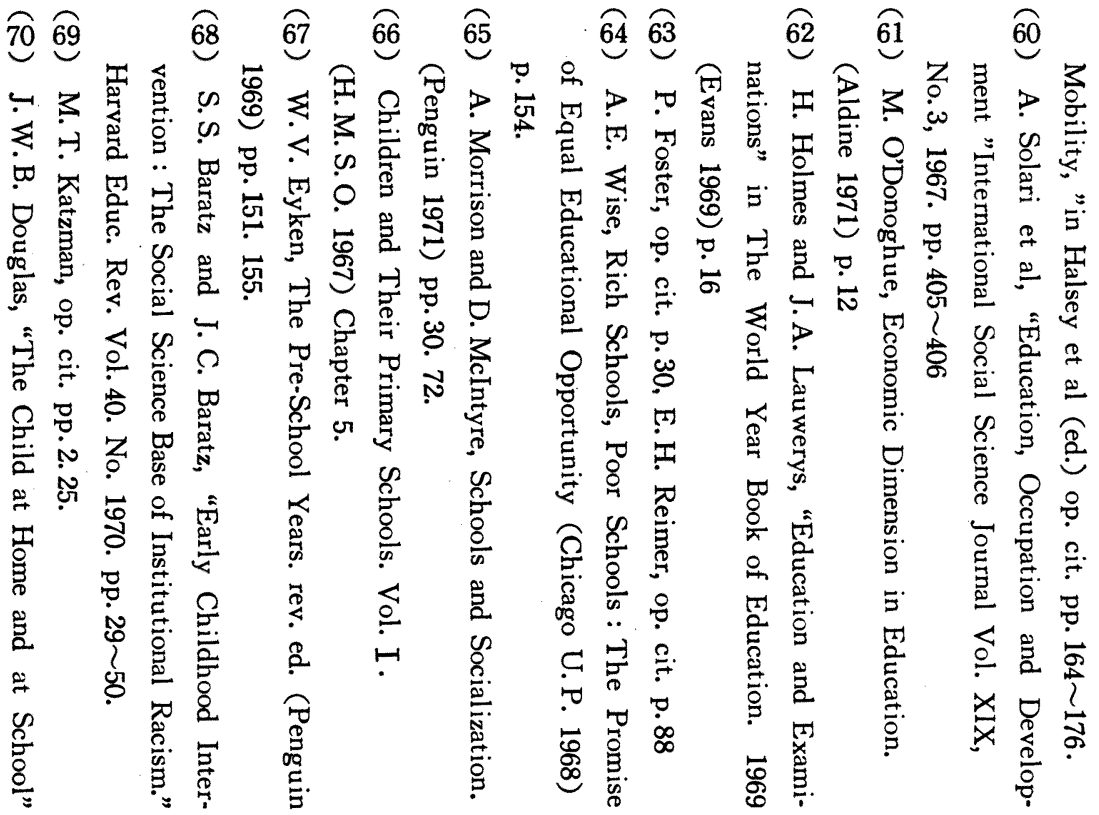


ฉำ

可穷

(I)

$\div$

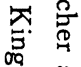

量

要

亏 Z

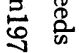

O

?

\% ?

5

(x)

苟 


\section{The Function of the School Reconsidered}

\section{Shogo Ichikawa}

(National Institute of Educational Research)

This essay will attempt to present some of the reasons why we have come to reconsider the function of the school in relation to social change.

Sociological problems are created when educational system comes to occupy a strategic place in an industrialized society and the school is regarded as a special agency responsible for educational tasks of that society. Therefore, we can say that industrialism gave rise to the sociology of education as a specialized field of study and, in fact, functionalism was par excellence the early sociologists' approach to educational institutions.

Nevertheless, educational sociologists had shifted their attention gradually towards the micro level problems such as the internal structure and organization of the school and the social relations inherent in educational activities, assuming that the school was performing its function as smoothly as expected.

Since World War II, every nation has realized the significance of education and owing to that, the social function of the school came into the limelight again. Sociologists have come back to the macro level problems with confidence that the school could meet their expectations as it used to.

However, after the experience of the past two decades, we have come know that educational investment is not a royal road to economic development, and educational attainment does not always assure a democratic society. It is now evident that the interrelationship between education and the wider social structure is far more complex than was at first supposed.

And what is more, we cannot but admit that dysfunction of the school is increasing all over the world. We should also look carefully into the existence of a gap between role expectation and real function of the school. Besides, development of knowledge industry and introduction of lifelong education scheme have obscured the feature of the school compared with other educational forms.

As a result, since the late 1960's an idea reconsidering it's function has been formulated and there is every indication reexamining the social role of the school in a new situation. 
What is necessary today in reviewing the function of the school is to present an orderly and coherent analysis of new social roles for the school in a post-industrialized society.

\section{A School in Community}

\section{Kenzo Mizoguchi}

(Yamagata University)

A school in community should generally have a close and good connection with people there for its good management which is further supported by the people.

But this connection tends to be broken up by a great change in life patterns in community caused by the recent economic growth.

A school and the people in a small rural community in particular have kept a better relation between them, because they have made much effort to promote mutual benefits; the one provided with such services as performed by the teachers to act as a consultant or guide to the people for their recreational activities, meetings and movements of various kinds; the other supported the school for its maintenance with their money and services. Thus, the school played as a community center, and fitted itself to the life patterns of the people in rural districts.

The distribution of children inhaited in districts was vastly changed accompanied by a great deal of urbanization and depopulation with a result that many schools were newly built in cities on one hand and many schools were demolished or consolidated in the countryside on the other.

A close relation between school and community which have been broken up by population movement, should be reconstructed but with a different, newly fitted type to changed life patterns.

A school district in Japan since the Meiji Restoration has been coincided to a government district. When a government district is enlarged by some reasons of governmental efficiency, a school district is to be enlarged not by people's conveniences.

We are now confronted with a new question to rebuild a fresh school district suitable for the people inhabited at changing life-circle.

This new school district planned by the people and the school is supposed to be reconstructed systematically on the core of children's 